\title{
论水利工程对生态环境的影响评价
}

张晓原

水利部新疆维吾尔自治区水利水电勘测设计研究院

DOI:10.32629/eep.v3i2.650

[摘 要] 水利水电工程是十分重要的民生工程, 由于施工技术和施工水平有限,水利工程建设中也会对生态环境造成不同程度的影响。在工程 建设中,应建立更为科学和完善的生态环境影响评价指标体系,进而明确生态环境破坏现状,采取有效的改进措施。本文就将分析水利工程对生 态环境的影响评价, 以供参考。

[关键词] 水利工程; 生态环境; 影响评价

水利工程环境影响评价涉及到的内容较多, 水利工程环境影响评价复 杂性较强, 且现阶段并未建设完善的评价体系。如今, 我国环境问题日益严 重, 人们也更加关注环境保护, 在水利工程建设中, 做好环境影响评价工作 也成为了较为关键的内容。

\section{1 水利工程生态环境影响评价原则分析}

1. 1 可持续性原则

为切实响应国家可持续发展的号召, 要加大环保力度, 减少资源消耗。 水利工程建设方, 需严格控制水利工程建设对周边环境的负面影响, 发挥 出水利工程的优势功能, 改善工程周边的生态环境。

\section{2整体性原则}

生态环境影响评价是评估水利工程建设对周边生态环境影响的一种有 效途径, 其涵盖工程建设的多个领域, 工程建设者和当地的居民均为其考虑 的主体。另外, 在建设的过程中要与多个部门建立联动关系, 不断减轻工程 建设对生态环境的损害, 完善评价体系, 根据实际制定针对性发展规划。

\section{3 综合性原则}

评价工作与工程建设的诸多方面均有着密切的关系, 一方面要关注工 程建设对社会的影响, 另一方面还需评价工程建设对当地自然环境及人文 环境的影响, 增强体系的全面性。

\section{2 环境影响评价需求分析}

\section{1 水资源开发}

水利工程规划和建设的过程中,一方面要关注水资源的经济效益, 另 一方面还需注重其在生态建设上的作用。水资源开发利用时, 如开发利用 力度超出自然所能承受的范围, 则会对生态环境构成十分显著的负面影 响。所以, 在工程建设阶段, 一方面要采取有效措施尽可能的提升工程的经 济效益, 同时也不可忽视经济效益和生态效益的平衡关系, 以此实现工程 建设的可持续发展。

\section{2 防洪工程}

洪水的作用具有十分显著的两面性, 洪水威胁了人民的安全, 所以在 社会发展的过程中, 防洪设施的建设数量明显增多。但是洪水在维护生态 平衡方面也发挥着一定的作用。适量洪水能够维护湿地干旱地区的生态平 衡, 如荒漠地区的生态、河流下游的河谷生态均可以洪水作为水源的重要 补充。所以, 如在上述地区建设防洪工程, 施工人员需结合实际采取相应措 施发挥出洪水的积极作用, 从而有效改善生态环境, 调节生态平衡。

\section{3 土地资源开发}

修建水利工程的过程中需要占用较多的土地资源, 其中涵盖工程占用 的土地、水体淹没的土地, 也有移民安置的土地。施工中需要适度调整和 改变土地资源的应用模式, 但这会使原有用地结构发生变化, 甚至导致部 分用地类型完全消失, 进而破坏当地的生态环境。我国西部地区的地理位
置特殊, 降水量较少, 生态环境容易受到外部因素的影响。为此, 在建设水 利工程时, 需立足生态资源及生物多样性的保护方面, 加强环评方案的可 行性和科学性。

\section{3 不同阶段环境影响评价的要点}

3. 1 项目规划

水利工程规划立项中, 要以宏观角度开展环境影响评价, 分析修建 水利工程对工程周边地区生态环境的影响, 明确工程建设可能引发的生 态环境问题, 判断当前环境问题发展的整体趋势, 以此为基础做好项目 立项工作。

3. 2 可行性研究

明确当地没有影响工程建设的环境因素后, 工作人员应及时编制项目 建设环境影响评价报告书, 从环境保护入手, 明确工程建设的科学性与可 行性。在环境影响评价工作中, 对工程建设可能引发的生态环境问题采取 科学有效的应对措施, 且将其与工程设计充分结合, 以工程概估算方式将 环保投资计入工程总概算。

3. 3 初步设计

初步设计时, 需细化上一阶段提出的环保措施, 分析评价环保措施 具体设计工程量、工程造价, 充分体现出工程特性。环境保护的过程中, 需采取满足工程管理要求的多种针对性管理措施, 且选择资质合格的环 境管理负责人、执行人, 为其下发管理的主要任务, 以推动项目验收工作 的顺利开展。

\section{4 环境影响评价中的注意事项}

4. 1 确定环境保护责任

水利工程环境影响评价的重点在于分析工程建设是否会加重原有的 环境问题, 或引发全新的环境问题, 同时准确区分区域原有的生态环境问 题以及加重的环境问题。环境影响评价工作的主要目标是减缓、减少、防 治工程建设中可能引发的环境问题, 确定建设方的主要责任, 督促工程建 设方采取有效的环境保护措施，进而控制工程建设造成的环境破坏。

\section{2 完善工程设计}

环境影响评价能完善, 帮助调整工程设计, 实现了环境需求与设计方 案的深度融合, 确保设计方案充分满足环境建设的基本要求, 减少工程建 设对生态环境的不利影响。在日常工作中,应立足环境保护, 综合考虑工程 任务、规模、占地和施工方案等科学评价工程设计方案的可行性, 且据此 提出科学有效的环保策略。再者, 工作人员也需关注环评专业与移民专业、 水土保持专业和规划设计专业等多个专业之间的联系与区别, 不同专业的 工作内容、工作范围和基本的工作思路存在着十分明显的不同又相互关 联。理清本专业与其他专业之间的关系, 这有助于提出更加准确的环境影 响预测和控制措施。 


\title{
武定县林下经济产业发展分析
}

\author{
李学富 \\ 武定县林业和草原局 \\ DOI:10.32629/eep.v3i2.681
}

[摘 要] 本文结合武定县的林业工作实践,认真分析了发展武定县林下经济产业的重要性即充分利用丰富的林下资源, 提高了土地的使用率进 而提高林副业产量,增加林下经济产业的经济效益。武定县林下经济产业发展现状主要包括林下养殖业、林下种植业、林下采集业和森林旅游。 但林下经济产业发展过程中存在资金扶持不足、后续政策保障不力、缺乏组织领导、规划不合理等问题,针对上述问题提出了加大扶持资金投 入、完善后继政策措施、建立组织领导机构、合理进行规划的建议和解决措施。近年来, 政府加大扶持资金投入, 完善后继政策措施, 培植龙头 企业,建立以政府为主导的组织领导层机构,合理进行产业规划等措施,使武定县的林下经济产业得到又好又快长久可持续的发展。

[关键词] 林下经济; 产业; 发展

\section{1 发展林下经济产业的重要性}

地面进行农作物、药类、菌类的种植或者家畜的养殖, 地上部分用于 树木的种植生长, 这种林下经济模式对于当地农民来说意义重大, 对于林 农增加林副业产品的数量和种类也是有很大帮助的。

林下经济产业结构复杂, 涵盖了林业、农业、畜牧业等行业。整个经 济产业中涉及的林牧副业产品的数量也非常多, 从植物到家禽, 从药类到 菌类。发展林下经济可以充分利用丰富的林下资源, 有效提高土地的使用 率。同时, 发展林下经济有利于提高产量, 增加林下经济产业的经济效益。

\section{2 武定县林下经济产业发展现状}

目前, 武定县的林下经济产业主要有林下养殖业、林下种植业、林下 采集业和森林旅游。

2. 1 林下养殖业

林下养殖是武定县发展林下经济产业规模最大, 参与户数最多的一种 模式。武定县林下养殖主要是林下黑山羊养殖和林下武定壮鸡养殖, 据武 定县畜牧局统计数据：2012年全县年出栏 $20 \sim 49$ 只以上的黑山羊养殖户 5600 户, 年出栏 16.8 万只, 年出栏 $50 \sim 99$ 只以上的黑山羊养殖户 353 户, 年

现阶段, 环境影响评价工作与工程设计的融合深度还存在一定问题, 无法全面展现其完善工程设计的作用。环境影响评价工作中, 很多工作人 员将重点放在评价环节, 不能针对当前存在的主要环境问题采取可靠的治 理和控制措施。此外, 在日常工作中, 环保资金无法得到有效落实, 这使得 环境影响评价工作无法落到实处, 不能实现理想的环境保护效果。为改变 现状, 环境影响评价人员应积极与规划设计人员展开沟通和交流, 做好各 方面的协调工作, 确保环境影响评价工作的科学性及可行性, 以此实现工 程设计与环境需求的有机结合。

\section{3以评价为基础采取针对性控制措施}

环境影响评价的主要目的是采取有效的环境保护措施以改善生态环 境。工作人员需结合环境影响评价预测可能出现的环境问题, 从而制定科 学有效的环保措施, 加大管理力度。在日常工作中, 明确工作的主要负责人 和执行者, 确定水利工程建设方的主要责任, 大力落实各项环保措施及管 理制度。

\section{5 工程实例分析}

$\mathrm{A}$ 市水务部门建设水利工程时开展了全方位的环境影响评价工作, 工作 人员对辖区内的水利工程进行了合理规划。现阶段, 工程多个项目均平稳运 行。部分水利配套设施已经得以应用, 同时取得了较为显著的成果。水利工 程建设投资约为 2152.35 万元, 辖区内的井灌区设计装设低压输水管道工程,
出栏 2.9 万只, 年出栏 $100 \sim 199$ 只以上的养殖户 73 户, 年出栏 1.1 万只, 年出 栏 300 只以上的养殖户 2 户, 年出栏 0.07 万只。2013年全县武定壮鸡存栏达 189.8 万只, 出栏 533.2 万只, 年产值 32.24 万元, 全县拥有出栏 100 只以上的 养殖户 1213 户, 出栏 1000 只以上的养殖户 75 户。

2. 2 林下种植业

林下种植的模式很多, 武定县主要有林粮间作模式、林烟间作模式、 林药间作模式。

林粮间作模式: 武定县林粮间作模式主要是在核桃、板栗新造林地块 内, 在新造林地前 5 年树冠较小的核桃、板栗株行距内间作矮稿作物。据统 计, 2015 年全县林粮间作面积已达 $6000 \mathrm{hm}^{2}$, 年产值可达 7000 多万元。

林烟间作模式: 林烟间作模式主要分布在白路镇、高桥镇、猫街镇、 已衣镇和发窝乡。特别是白路镇, 既是核桃种植面积最多的地区也是烤烟 生产任务最重的地区, 每年林烟间作面积 $1300 \mathrm{hm}^{2}$, 据统计, 武定县 2015 年 林烟间作面积达 $2000 \mathrm{hm}^{2}$, 创年产值 1.2 亿元。

林药间作模式: 以武定县白路白药集团基地为代表, 带动万年青经贸有 限责任公司等多家企业在林下种植中草药, 至2015年全县共种植续断 $450 \mathrm{hm}^{2}$,

且设置50套农村节流灌溉监测控制柜, 150 个机井智能控制保护柜, 配洜 120 台套, 维修了18座小塘, 且新修建了 2 座小塘坝。工程建设施工后, 显著增加 了灌溉面积, 灌溉水利用系数显著增大, 节约了大量的水资源和电力资源, 而且也减少了土地占用和人力成本, 真正达到了增产增收的目标。

\section{6 结语}

如今, 我国水利工程建设事业持续前行, 在发展的过程中也对当地的 生态环境产生了一定的破坏。为减少水利工程建设对生态环境的破坏, 在 工程建设的过程中, 必须坚持建设的整体原则, 参照工程实际不断优化和 完善环境影响评价工作, 以优质的环境影响评价工作指导水利工程建设, 推动我国水利事业的健康发展。

\section{[参考文献]}

[1]刘晓龙,段小芳.水利工程对生态环境的影响评价[J].时代农 机,2018(4):91.

[2]毛力.试述水利工程施工建设对生态环境的影响 [J]. 江西建 材,2018(1):87.

[3]沙丽旦那提 - 苏里坦别克.水利工程建设对生态环境的影响分析 [J]. 江西农业,2017(11):71.

[4]李晨阳. 浅谈水利工程建设对生态环境的影响 [J]. 科技 风,2019(22):183. 